\title{
Performance of Four Commercial Tomato Varieties in Southern Puerto Rico ${ }^{1}$
}

\author{
Gerardo Mangual-Crespo and Lourdes Castro ${ }^{2}$
}

\begin{abstract}
Tomato varieties Count, Duke, Floradade, and HB Castle scored acceptable marketable yields in five pickings: 41,$439 ; 41,363 ; 39,685$; and $36,223 \mathrm{~kg} / \mathrm{ha}$, respectively. In number of marketable fruits/ha, Count $(65,229)$ significantly outyielded variety HB Castle $(39,450)$, but it did not significantly outyield Duke $(54,089)$ or Floradade $(53,658)$. The highest marketable individual picking was that of HB Castle, with $18,329 \mathrm{~kg} / \mathrm{ha}$ on the fourth picking ( 88 days after planting).
\end{abstract}

\section{INTRODUCTION}

Local tomato production in Puerto Rico for 1979-80 amounted to 3,600 metric tons, with a farm value of $\$ 1,494,000$. Fresh tomato imports from the United States for the same period amounted to 15,250 metric tons with a cash value of $\$ 6,405,000$. The net value of the US imported processed tomatoes totaled $\$ 11,935,000$ (3).

Commercial tomatoes are planted in Puerto Rico from December to March, the drier cooler months. Excessive rainfall and high temperatures during May through September reduce tomato yields greatly, mainly because of the high incidence of diseases and the dropping of flowers and small fruits.

Various authors have reported data regarding the optimum temperature for the flowering and development of tomato. Marrero (6) indicated that optimum temperature is between 15 and $18^{\circ} \mathrm{C}$. Relative humidity over $60 \%$ hinders pollination because pollen grains swell, thus increasing the percentage of fallen flowers and small fruits. Lambeth (4) reported that temperatures over $26^{\circ} \mathrm{C}$ within 24 hours after anthesis, reduced pod set in snap bean variety Tendergreen, thus reducing yield.

Commerical tomato varieties planted throughout the Caribbean area (2) come from the southern United States. These varieties, although producing reasonable yields of 26-38 tons/ha, are not adapted to our climatic conditions and yield well only during the cooler months of October to April.

The lack of tomato varieties capable of producing fruits of excellent quality throughout the year under our climatic conditions has been a limiting factor in tomato production in the island.

${ }^{1}$ Manuscript submitted to Editorial Board September 8, 1982.

${ }^{2}$ Assistant Agronomist and Research Assistant, respectively, Agricultural Experiment Station, Mayagüez Campus, University of Puerto Rico. Jorge Jiménez, Research Assistant, Fortuna Substation, helped prepare the seedbeds and the Experimental layout. 
The purpose of this work was to evaluate the performance of four commercial tomato varieties under the conditions of southern Puerto Rico.

\section{MATERIALS AND METHODS}

A tomato experiment consisting of seedlings of four commercial varieties was planted December 21, 1981 at the Fortuna Agricultural Experiment Substation in southern Puerto Rico, in a San Antón silt loam (Cumulic Haplustolls, fine-loamy, mixed, nonacid, isohyperthermic (5).

A complete block design with five replications and varieties Duke, Floradade, Count and HB Castle was used. Seedlings were planted by hand approximately $45 \mathrm{~cm}$ within the row in rows $1.5 \mathrm{~m}$ apart and $6 \mathrm{~m}$ long. Diphenamide ${ }^{3}$ was applied as a preemergent herbicide immediately after planting at the rate of $13.34 \mathrm{~kg} / \mathrm{ha}$. A weekly preventive spraying program was followed, a mixture of Diazinon AG 500 and Dithane M-45

TABLE 1.-Climatic conditions prevailing at Fortuna Substation during the experimental cycle

\begin{tabular}{|c|c|c|c|c|c|}
\hline \multirow{2}{*}{ Period } & \multicolumn{2}{|c|}{ Mean temperature } & \multirow{2}{*}{$\begin{array}{l}\text { Wind } \\
\text { velocity }\end{array}$} & \multirow{2}{*}{ Evaporation } & \multirow{2}{*}{ Rainfall } \\
\hline & Min & $\operatorname{Max}$ & & & \\
\hline & ${ }^{\circ} \mathrm{C}$ & ${ }^{\circ} \mathrm{C}$ & $\mathrm{km} / \mathrm{hr}$ & $m m$ & $\mathrm{~mm}$ \\
\hline 21-31 December/81 & 21 & 31 & 29 & 4 & 6 \\
\hline 1 -31 January /82 & 19 & 30 & 59 & 5 & 1 \\
\hline $1-28$ February / 82 & 20 & 30 & 48 & 5 & 11 \\
\hline 1 -31. March /82 & 19 & 32 & 53 & 7 & 14 \\
\hline $1-5$ April & 20 & 31 & 58 & 6 & 1 \\
\hline
\end{tabular}

at the rate of $1200 \mathrm{ml}$ and $2.25 \mathrm{~kg} / \mathrm{ha}$, respectively, to reduce damage by insects and diseases. Irrigation was applied as necessary.

The plants were picked five times starting February 23, 1982, and ending April 2, 1982. Data from each picking was recorded for total, marketable, and cull fruits.

\section{RESULTS AND DISCUSSION}

Table 1 shows the climatic conditions which prevailed during the experimental cycle. Temperatures were way over the optimum for flowering and fruit setting as found by Marrero (6).

Table 2 shows the marketable yields of the four varieties. Yields of the first two pickings were very low, especially those of the first one.

\footnotetext{
${ }^{3}$ Trade names in this publication are used only to provide specific information. Mention of a trade name does not constitute a warranty of equipment or materials by the Agricultural Experiment Station of the University of Puerto Rico, nor is this mention a statement of preference over other equipment or materials.
} 
Duke and Count showed no statistical difference in marketable yield in the first picking, but both were significantly superior to Floradade and $\mathrm{HB}$ Castle. In the second picking, Duke outyielded significantly varieties Floradade, Count and HB Castle, but there were no significant differences between the varieties in the third, fourth or fifth pickings. The peak of the harvest occurred in the fourth picking, in which BH Castle produced the highest marketable yield with $18,329 \mathrm{~kg} / \mathrm{ha}$.

In the combined analysis for the five pickings, there were no significant differences between the marketable yields of the four varieties, even though Count yielded highest with $41,440 \mathrm{~kg} / \mathrm{ha}$, followed very closely by Duke with 41,303 and Floradade with 39,685. HB Castle fell a little behind with $36,223 \mathrm{~kg} / \mathrm{ha}$.

The total number of fruits per hectare for the five pickings was 389,976 ; 378,082; 346,490 and 326,577 for Count, Floradade, Duke and HB Castle, respectively. Count was significantly superior to HB Castle and Duke; Floradade was superior to HB Castle but not to the others.

TABLE 2.-Marketable yield of four commercial tomato varieties planted at Fortuna Substation December, 1981

\begin{tabular}{lcccccc}
\hline \multirow{2}{*}{ Variety } & \multicolumn{5}{c}{ Selective pickings } & $\begin{array}{c}\text { Combined yield of } \\
\text { five pickings }\end{array}$ \\
\cline { 2 - 5 } & $2 / 23 / 82$ & $3 / 2 / 82$ & $3 / 10 / 82$ & $3 / 19 / 82$ & $4 / 2 / 82$ & $\mathrm{~kg} / \mathrm{ha}$ \\
Duke & $\mathrm{kg} / \mathrm{ha}$ & $\mathrm{kg} / \mathrm{ha}$ & $\mathrm{kg} / \mathrm{ha}$ & $\mathrm{kg} / \mathrm{ha}$ & $\mathrm{kg} / \mathrm{ha}$ & $41,303 \mathrm{a}$ \\
Floradade & $312 \mathrm{a}^{1}$ & $6,594 \mathrm{a}$ & $11,454 \mathrm{a}$ & $16,859 \mathrm{a}$ & $6,084 \mathrm{a}$ & $39,685 \mathrm{a}$ \\
Count & $63 \mathrm{~b}$ & $3,606 \mathrm{~b}$ & $9,587 \mathrm{a}$ & $14,174 \mathrm{a}$ & $12,255 \mathrm{a}$ & $41,440 \mathrm{a}$ \\
HB Castle & $266 \mathrm{a}$ & $3,301 \mathrm{~b}$ & $10,815 \mathrm{a}$ & $16,727 \mathrm{a}$ & $10,331 \mathrm{a}$ & $36,223 \mathrm{a}$ \\
\hline
\end{tabular}

${ }^{1}$ Values in columns followed by different letters differ at the $0.05 \%$ probability level.

Duke registered $47,524 \mathrm{~kg} / \mathrm{ha}$ in total weight of fruits for the five pickings; Duke and Count $(47,392)$ were statistically superior to $\mathrm{HB}$ Castle $(40,207)$. Floradade yielded $44,880 \mathrm{~kg} / \mathrm{ha}$.

Yields in this trial compare favorably with the $8,182-19,545 \mathrm{~kg} / \mathrm{ha}$ reported by Abrams et al. (1) in an NPK experiment at Isabela with Floradel, one of our leading tomato varieties. They also compare favorably with yields of 39,520 and $37,050 \mathrm{~kg} / \mathrm{ha}$ reported by Pérez-Zapata et al. (7) for varieties Floralou and Marglobe, respectively, for a summer planting at Lajas. However, these authors reported outstanding yields of $68,935 \mathrm{~kg} / \mathrm{ha}$ for the same varieties during winter plantings.

\section{RESUMEN}

Una siembra de tomates se estableció en la Subestación Experimental de Fortuna, en la costa semiárida del sur, para evaluar los rendimientos de cuatro variedades comerciales. 
Los rendimientos commerciales de las variedades Count, Duke, Floradade y HB Castle fueron: 41,439, 41,303, 39,685 y 36,223 kg/ha, respectivamente.

En número de frutas comerciales por hectárea la variedad Count $(65,229)$ superó significativamente a la HB Castle $(39,450)$, pero no a las Duke $(54,089)$ y Floradade $(53,658)$.

La cogida de frutas comerciales/ha más alta correspondió a HB Castle con $18,329 \mathrm{~kg}$ a los 88 días.

\section{LITERATURE CITED}

1. Abrams, R., L. Cruz-Pérez, R. Pietri-Oms and F. J. Juliá, 1975. Effect of fertilizer N, P, K, Ca, Mg, and Si on tomato yields in an Oxisol. J. Agric. UPR. 59 (1): 26-34.

2. Annais, G. and P. Daly, 1973. Tomato variety selections and cultural practices for the Caribbean, Caribbean Food Crops Soc. Proc. 11: 161-66.

3. Facts and Figures on Puerto Rico's Agriculture. Commonwealth of Puerto Rico, Dep. of Agriculture, Office of Agricultural Statistics, 1978-79, 1979-80.

4. Lambeth, V. N., 1950. Some factors influencing pod set and yield of the lima bean, Miss. Agric. Exp. Stn. Res. Bull. 466.

5. Lugo-López, M. A., Bartelli, L. and Abruña, F., 1973. An overview of the soils of Puerto Rico. Classification and physical, chemical and mineralogical properties, Agric. Exp. Stn. Univ. P.R. Publ. 79.

6. Marrero, P., 1978. Influencias de la temperatura y la luz sobre el crecimiento y desarrollo del tomate. Boletín de Reseñas No. 1, Ed. Centro de Información y Documentos Agropecuarios, La Habana, Cuba.

7. Pérez-Zapata, M. and G. Ramírez-Oliveras, 1980. Effect of season and growth regulators on flowering, fruit set and development of the tomato, J. Agric. Univ. P. R. 62 (4): $460-73$. 